doi: $10.19090 / \mathrm{i} .2018 .29 .48-62$

UDC: 929 Follia M.

ISTRAŽIVANJA

JOURNAL OF HISTORICAL RESEARCHES

$29(2018)$
ORIGINAL SCIENTIFIC PAPER

Received: 17 June 2018

Accepted: 30 July 2018

ĐURA HARDI

University of Novi Sad

Faculty of Philosophy, Department of History

djurahardi@ff.uns.ac.rs

\title{
MARIA FOLLIA, A COURT LADY \\ OF THE HUNGARIAN QUEEN ELIZABETH LOKIETEK, ACCOMPANYING HER MISTRESS ON A JOURNEY TO ITALY*
}

\begin{abstract}
The journey and stay of the Hungarian queen Elizabeth Łokietek, mother of King Lajos the Great and widow of King Charles Robert, to the Kingdoms of Naples and Rome from June 1343 until May 1344, is a well-researched topic in historiography. On that journey the queen was accompanied, as a Hungarian chronicler noted, by her court, numerous ladies-in-waiting, girls of noble origin, Hungarian barons, knights and servants. Yet, of all the women accompanying the queen, only the identity of one of her court ladies is known, that of aristocrat Maria Follia. Her presence in the (closest) surrounding of the queen is testified by two diplomatic sources, one of Hungarian and another of Naples provenance. Maria was the widow of a recently deceased Hungarian palatine William Drugeth (who died in September 1342). The author in this paper investigates the causes and complex circumstances under which Maria Follia participated in the Italian journey of her mistress. The issue is all the more interesting since it is known that, after the death of palatine William, the Drugeth family, until then the most powerful Hungarian baron family, lost their wealth, fortune and positions in the royal court. One of the possible answers to this question is a conclusion that the palatine's widow, independent of her husband's family, stayed in good relations with Queen Elizabeth and kept her positions in the royal court.
\end{abstract}

Keywords: Maria Follia, Hungarian queen Elizabeth Łokietek, Drugeth family, William Drugeth, widows in the $14^{\text {th }}$ century, Hungary under the Anjou rule, Hungarian-Naples relations.

$\mathrm{B}$ ecause of the royal splendor, pomp and wealth that followed it at every turn, the almost one-year stay of the Hungarian queen Elizabeth Łokietek (Lokietek Erzsébet) in Italy left a great impression on her contemporaries. The open political ambitions of this endeavour largely surpassed its religious intention of a pilgrimage to sacred places. In this dual context, the visit of Elizabeth Łokietek to Naples and Rome was

\footnotetext{
* The paper is a result of the research project The region of Vojvodina in the context of European history (no. 177002) funded by the Ministry of Education, Science and Technological Development of the Republic of Serbia.
} 
duly researched in historiography, starting with the unavoidable studies of János Karácsonyi and Antal Pór, then in the work of Elizabeth's biographer Jan Dąbrowski, as well as in the works of István Miskolczy, Bálint Hóman and, more recently, Csukovits Enikő. ${ }^{1}$ As for the contemporaries of Queen Elizabeth, i.e. narrative sources whose descriptions were used to a great extent by historians to formulate their descriptions and conclusions, there are two sources - the main chronicler of the rule of Elizabeth's son, King Lajos the Great, János Küküllei (Ioannes de Kykullew), ${ }^{2}$ as well as the equally significant anonymous Roman chronicler who was a witness to the Queen's visit to the eternal city. ${ }^{3}$ Küküllei was also acquainted with the precious details regarding Elizabeth's Italian travels and it is likely he was a direct witness to those events. ${ }^{4}$

It had been half a year since King Charles Robert Anjou died in Hungary (16 July 1242), when a message from the Kingdom of Naples arrived to the Hungarian royal court in Visegrad saying that Charles' uncle, King Robert the Wise, died there (20 January 1343). ${ }^{5}$ In the meantime, the ambitious Hungarian queen Elizabeth took power in the country on behalf of her son young King Lajos so now she had to inevitably prepare for a trip to distant Italy. There was no discussion of peaceful days that would become a grieving royal widow.

The Queen mother was justifiably concerned about her younger son, Prince András, who was separated from her at the age of six and sent to live at the Naples royal court. That was dictated by the dynastic interests. Elizabeth's husband, Charles Robert, took his second son to Naples in 1333, where on 27 September an official engagement ceremony was held (i.e. a marriage which waited to be confirmed by "consummation") between the underage bride and groom, the little Hungarian prince András, who on that occasion became Prince of Calabria, and the seven-year-old Naples princess Joanna (Giovanna), a granddaughter of King Robert. This event was preceded by complex negotiations between the two sides mediated by the Roman Curia. According to the terms of the agreement that was reached, András as a representative of the older branch of the Anjou Dynasty that left its roots in Hungary (from 1301), through the marriage to Robert's granddaughter and successor Joanna, was determined to be the crown prince of the Naples kingdom. This meant that one day he would replace King Robert on the throne. Under these circumstances, Charles Robert left his son with a small Hungarian escort in the capital of Apulia, where he grew up to be prepared for the future role of a ruler, and returned to Hungary. At the court in Naples, however, Prince András was treated as a foreigner and an intruder. The arrival of this child ruined many of their plans. Surrounded by enemies who spun a web of intrigue around him, the young prince of Calabria remained deprived of all the honors that belonged to the heir to the throne and was kept away from the real power. The conflicting court parties, among which were the younger lines of the Anjou dynasty from the families of princes Taranto and Durazzo, fought to gain the affection of the grandchildren of King Robert, Princess Joanna and her younger sister Maria, who were essentially regarded as successors to the throne of

${ }^{1}$ Karácsonyi 1893: 50-63; Pór 1892: 46-54; Id. 1893: 680-683; Dąbrowski 1914: 51-57; Miskolczy, 1937: 48-50 Hóman 1938: 322-324; Csukovits 2003: 70-71.

${ }^{2}$ Ch.H: 162-165; SRH, I, 284-287.

${ }^{3}$ Hist. Rom. Fragmenta: 316-320.

${ }^{4}$ On Janos Küküllei with literature review: Köblös 1994: 387; Szende 2005; 336-337.

${ }^{5}$ Kristó - Makk 1988: 49-50; Caggese 1930: 424-426. 
the Kingdom of Sicily. Under the influence of the surroundings, before his death King Robert annulled the former agreement reached with his nephew, Charles Robert. In his will Robert stipulated that only his granddaughter could be crowned the ruler of the Kingdom of Sicily and that Charles' son was intended only to be the queen's husband. In the case their marriage produced no children, the succession of the kingdom would be passed to Joanna's younger sister. It was determined that until Joanna turned 25 the country would be run by a regency appointed by the Pope as a sovereign of the country, which would be formally led by Robert's widow. At the moment of King Robert's death at the court in Naples the struggle between the parties became even more intense. The Hungarian queen Elizabeth, who apparently did not lack information about the position of her son, took it as a sign to act quickly and, by appearing in Naples, to protect the legitimate rights of her dynasty. ${ }^{6}$

As János Küküllei informs us, the reason for Elizabeth's arrival to Italy was not only the queen's visit to a son who "still did not rule in Apulia," but her vow that, after the death of her husband King Charles she would visit the relics of the holy apostles St. Peter and St. Paul in Rome. ${ }^{7}$ If essential political reasons are left aside, it might be noticed that after ten years it was an opportunity for the queen to see her son, now already a young man, and to finally meet her daughter-in-law and her family, as well as to see a warm sea and a country in the heart of Christian Europe, probably for the first time in her life. The main political goal of the mission was determined beforehand: to put pressure on the court in Naples and the pope and, in accordance with the earlier agreement, to crown András the King of Sicily. ${ }^{8}$ For this purpose, Elizabeth brought with her a huge amount of money, the amount of which became a common place in historiography as a paradigm of successful financial reforms that Charles Robert (together with associates) conducted in Hungary. ${ }^{9}$ According to the aforementioned chronicler, the queen had at her disposal 27,000 marks of fine silver and 17,000 marks of pure gold. In addition, her son King Lajos sent her an additional 4,000 gold marks. Besides, she also had half a bushel (media garleta) of golden florins, not counting the change intended for giving to the poor on her journey. ${ }^{10}$ On the other hand, other luxurious gifts for the hosts and their sanctuaries were carefully prepared in Visegrad. Finally, enormous treasure in money and luxurious gifts was not only intended to buy support for Prince András' coronation, but also to demonstrate the power and prestige of the Hungarian branch of the Anjou dynasty.

At the beginning of a large court procession on 8 June 1343 Queen Elizabeth headed from Visegrad on the Danube towards the Adriatic Sea along the usual path of the old Roman road. On the shore two Venetian galleys were waiting for her. Crossing the steady sea the expedition arrived to Apulia, where Elizabeth was met by her son András and his wife Joanna. They took her to Naples, where she officially arrived on 24 July $1343 .{ }^{11}$ It is not our goal to closely monitor Elizabeth's stay in Italy, as we have already noted, because

\footnotetext{
${ }^{6}$ Miskolczy, Magyar-olasz összeköttetések, 21-31; Caggese 1922: 665-667, 671; Caggese 1930: 424-425; Hóman 1938: 318-322; Léonard 1954: 315-319, 343-344.

${ }^{7}$ Ch. H: 162.

${ }^{8}$ Karácsonyi 1893: 51-52.

${ }^{9}$ For example: Hóman 1921: 179-180.

${ }^{10}$ Ch. H: 162-163.

${ }^{11}$ Karácsonyi 1893: 53-54; Pór 1893: 681.
} 
in this case we would only repeat facts known in historiography. In short, as far as the further itinerary of the queen is concerned, which is related to the topic of our paper, we will list the following facts. After directly seeing the position of her son on the Naples royal court, Elizabeth sent a distinguished delegation of Hungarian barons to the Pope in Avignon to get a consent for András' coronation, while she headed for Rome on 14 September with her entire court, accompanied by the aristocracy and clergy of Naples. During these three unforgettable days spent in the eternal city, where she was magnificently welcomed by Roman aristocracy and citizens, the queen visited the main churches and relics and returned to Naples on 11 October to stay with her hosts. Here she stayed here until the end of February 1344, when she and her escort went back to Hungary. The road led her through Bari, where she prayed to St. Nicholas, and she spent the first day of Easter (4 May) waiting for the ships in Manfredonia, to finally sail home after her son András sent her four galleys. On the other side of the Adriatic sea the queen landed at the port of Senj only to arrive home to Visegrad on the anniversary of her departure (et pervenit in domum suam in Wyssegrad in anniversario sui recessus), i.e. in May $1344,{ }^{12}$ where she was gladly welcomed by her sons, the King of Hungary Lajos and Prince István. ${ }^{13}$

It was noted that when Elizabeth arrived in Naples there were as many as 400 people in her company. ${ }^{14}$ As it became a queen (iuxta magnificentiam regiam), Elizabeth was accompanied by her entire court according to János Küküllei, which included numerous court ladies, girls of noble origin, barons, knights and protégés (clientes), and a large number of servants. ${ }^{15}$ Because of the first report of the aforementioned Hungarian chronicler, as well as because of preserved diplomatic sources, historiography has more than ten names of Hungarian secular and sacral barons and generals who accompanied the queen to Italy. Some of them continued to Avignon and then, independent of the queen, returned to Hungary. This group of dignitaries was led by two highest officials of the Hungarian royal court, palatine Nicholas (Miklós) Giletffy and the judge of the royal court Paul (Pál) Nagymártoni, and, when sacral dignitaries are concerned, by the bishop of Nitra and the count of the royal chapel (comes capelle) Vitus. ${ }^{16}$

However, of the female part of the queen's escort, which implied "multitudo dominarum et nobilium puellarum," again because of the available diplomatic sources, only the name of one Elizabeth's court lady was preserved, who was, truth be told, a distinguished aristocrat. This was Maria Follia, the widow of the palatine William Drugeth. Two documents, one Hungarian and another one of Naples provenance, testify to this fact. In the introductory part of our paper we shall rely on the description from the Hungarian source. On the basis of its content more than a hundred years ago Antal Pór (who, although he himself did not cite the source, obviously had it in mind) and Mór Wertner concluded that

\footnotetext{
${ }^{12}$ There are different opinions regarding the chronology of the queen's return to Visegrad: Pór 1892: 54; Mályusz 1988:103; Wertner 1905, 437; Dąbrowski 1914: 57; Hardi 2012: 368-369.

${ }^{13}$ Ch. H: 163-164; Mályusz 1988: 100-103; also compare note no. 1.

${ }^{14}$ Caggese, Roberto d'Angiò, I, 680.

15 „Domina igitur Elizabeth regina Hungarie... iter arripuit versus Italiam cum honesta familia et multitudine dominarum et nobilium puellarum, baronum, militum et clientum, cum multo et magno apparatu..." Ch. H: 162.

${ }^{16}$ For the identification of Hungarian dignitaries accompanying the queen: Karácsonyi 1893: 52-53; Pór 1893: 680- 681 .
} 
the "widow of the palatine William Drugeth" was on that occasion in the queen's escort. ${ }^{17}$ This is a court order issued by the office of the judiciary of the curia Paul in Visegrad on 17 March 1344 concerning the postponement of a court dispute over the possession of Radowanzegh in the Zemplin County ${ }^{18}$ between Tamás de Zeech (Szécsy) and Mook, son of Kooch, to the $15^{\text {th }}$ day of the return of Queen Elizabeth from the overseas regions (Italy) to Visegrad. Namely, the new hearing was scheduled because one side in the dispute, specifically the representative of the said Mook, pointed out that certain original copies of the royal charters that he wishes to present to the court were in the hands of the widow of the palatine William Drugeth (apud manus nobilis domine relicte domini Vyllermi Drugeth palatini) and that he would not be able to get them before the noble widow of the palatine, together with her mistress, returned to Visegrad from overseas countries (unacum domina nostra regina in Visegrad de partibus transmarinis veniret).$^{19}$ Meanwhile, while exploring the extraordinary history of the Drugeth family and having insight into the works of the aforementioned older historians, we did not miss the "detail" that Maria Follia accompanied the queen in 1343-1344 during her stay in Italy. ${ }^{20}$ This fact not only represented important material for the biography of Maria Follia as an exceptional Hungarian noblewoman of the Anjou period, but we also realized that this fact (we mean her journey to Italy as the nearest companion of the queen) as an important moment also related to the fate of the Drugeth family after 1342 in the light of the court politics of the successor Charles Robert. ${ }^{21}$ In any case, we felt that certain "contradictions" which will be discussed in the rest of the paper deserve a special discussion, whose conclusions could fit into the context of the preparations of Queen Elizabeth Łokietek concerning her visit to her younger son prince András and Anjou relatives in Naples.

Who was really Maria Follia? If we used the historiographic method of a typical identification of a medieval woman, and Hungary was not an exception in that respect, we would mention information on her marital status, namely that Maria was the wife of one of the most powerful Hungarian barons of that time, palatine William Drugeth. The representatives of the noble Drugeth family were French (in sources mentioned as "Gallici") originating from the kingdom of Naples. William's father Jean and Uncle Phillip had known the future king of Hungary Charles Robert since childhood, because they grew up together with him at the Royal Palace of Naples. When in 1300 Charles Robert as a pretender to the throne was sent to Hungary, his companion was Phillip Drugeth, who had a brilliant career in this foreign country. For many years, Phillip as the most faithful associate and military commander of Charles Roberts participated in the struggle of his master against other royal opponents and disobedient Hungarian noblemen who held true power in the country. Victorious in the end, Charles appointed Phillip the palatine of the Kingdom of Hungary at the beginning of 1323, which was the highest state position in the hierarchy of Hungarian barons. Previously, on behalf of the king, this Drugeth gained great power stretching over

\footnotetext{
${ }^{17}$ Pór 1892: 46; Id. 1893: 680; Wertner 1905, 437.

${ }^{18}$ Csánki 1890, 360; Uličný 2001, 418.

${ }^{19}$ Z, II, 105-107; Anjou, XXVII, no. 244, 150-151; Z, VII/1, 100.

${ }^{20}$ Hardi 2012: 364-370; Hardi 2014: 2018; lately the path of Maria Follia accompanying the queen was also acknowledged by: Zsoldos 2017: 75

${ }^{21}$ We wrote on Maria Follia in Hardi 2012: 353-379.
} 
the counties rich in silver which were located in the northeast of the country towards the border with Poland and Galicia and was rewarded with a royal donation of numerous properties in that territory. After Phillip's death (he died in 1327 without a male heir), Charles Robert invited other members of the Drugeth family to Hungary from France, where they stayed in the court service of his sister, the French queen Clementia of Hungary, the widow of Louis X. As the ruler decided, Phillip's large estate was inherited by his nephew William, while Phillip's older brother Jean took over the position of the palatine of the kingdom of Hungary. After his death his son William inherited this privilege. In this order, the Drugeths held the palatine rule for two decades (1323-1342) and at the peak of their power they managed 14 counties and, as their personal possession, kept as many as nine fortresses and at least as many others as royal barons. In a word, although foreigners, during the reign of Charles Robert (1301-1342) the Drugeths became the most powerful and richest baron family of Hungary. ${ }^{22}$

The aforementioned Maria Follia belonged to this aristocratic family. Her identity as the wife of William Drugeth was revealed on the basis of the content of William's last will by the first modern historian of this family, a famous erudite, genealogist and publisher of Hungarian medieval sources which mostly referred to the past of the counties of Spiš and Šariš (present-day eastern Slovakia), Karl Wagner (1732-1790). ${ }^{23}$ Regarding historical sources, Maria Follia came out of the shadow of anonymity on 9 August 1330, when she was mentioned in the aforementioned last will of her husband William, then the prefect of Spiš and Abaújvár. Although we have already analyzed the content of this document, because of deeper understanding of this topic we shall repeat, for the Hungarian circumstances of that time, a unique list of goods left by William to his wife in the case of his death. ${ }^{24}$ Besides an impressive amount of money in the amount of 1,000 marks of fine silver, Maria was to inherit “... ten large vessels of silver, twelve silver cups with one handle, three silver jugs with a long neck and one large, two smaller and four those for pouring water. Also one golden crown decorated with precious stones in the value of 100 marks of fine silver, eight small salt shakers, ten spoons of silver, ten deep red fabrics with gold plated threads, nineteen deep red silk fabrics, three silver belts, two larger and one smaller, and other jewelry which was taken to the Gönc fortress for safekeeping. Also to my wife, a large gilded cross decorated with precious stones that are kept in the fortress of Spiš..." ${ }^{25}$ As noted in historiography, the valuables of William's wife indicated not only direct wealth, but above all the difference in quality of life and the sense of luxury and sophistication, which set this family apart from the

\footnotetext{
${ }^{22}$ Hardi 2012; also compare: Zsoldos 2017.

${ }^{23}$ Wagner 1802: 34; for Karl Wagner compare: Malovecká 2009.

${ }^{24}$ Compare Hardi 2012: 297-312; Hardi 2014: 212-223.

25 „Item Domicelle Marie Foliye... decem magnas scutelas de argento, duodecim cifos argentateos in uno futro, tria angusturia argentea, unum magnum, duo minora et quartum illis minus ad fundendum aquam. Item unam coronam auream lapidibus pretiosis ornatam, centum marcis fini argenti comparatam, octo scutelas parvas argenteas pro salsa decem cochlearia de argento, decem cochlearia de argento, decem pannos de porphyraceis deauratis decem et nouem purpuras de serico factas... tres balteos, seu cingulos argenteos, duos maiores et unum minorem, et alia iocalia in castro de Gunch ad servandum deportata. Item eidem consorti mee unam crucem magnam de argento deauratam cum bonis lapidibus praeparatam in castro Scepus circa Magistrum Petrum custodiam... lego et relinquo.“ D1 71270.
} 
rest of the Anjou aristocracy in Hungary at that time. ${ }^{26}$ On the basis of the list of jewellry and expensive fabrics mentioned in her husband's will, we can rightly suppose that Maria Follia in her look and appearance was a role model in terms of fashion and aristocratic culture of daily life for many women at the royal court in Visegrad. ${ }^{27}$

It is important to state now that Maria Follia, as a member of one of the most powerful aristocratic families of Hungary at that time, at a first glance already had the place in the company of Queen Elizabeth on her planned journey to Italy. Finally, as the wife and recently widow of the palatine of Hungary, who was the closest associate of King Charles Robert during the 1340 's, she was also one of the most respected court ladies. However, this fact also covers the main problem and controversy of our paper, which we must resolve. Namely, as stated, Charles Robert died on 16 July 1342 and two months later, probably in mid-September (date ante quem 10. septembar), palatine William Drugeth unexpectedly left this world. ${ }^{28}$ According to Maria Follia's own words, as we learnt from one of her orders of 28 January 1343, her husband was caught by a frenzied death (festinum decessum) and from the subsequent text it can be concluded that it was caused by an unnamed disease that progressed rapidly. ${ }^{29}$ In the months that followed the death of William, the Drugeth family suffered a political and economic breakdown. Its male members lost their former high positions at the Royal Court, their main possessions and sources of economic and political power.

The cause of the fall of the Drugeths was the death of their main political protector, King Charles Robert, i.e. their previous enormous political power, because of which they apparently made many enemies. Their opponents now gathered around Queen Elizabeth and young King Lajos. While the old king was alive, we can conclude that the Drugeths' enemies were wise and silent. It was, in all likelihood, a political conflict between the "Gaelic" side or the Drugeths' side and the "Polish" side, which gathered around Queen Elizabeth. The cause, of course, was the death of William Drugeth and the circumstance that his marriage to Maria Follia produced no male heir, so it was believed that all of his belongings should be returned to the king. As it was first proven by Pál Engel - presenting a presupposition in historiography about the collapse of the political power of the Drugeth family after 1342 - the queen's people led by her cousin, the-then Duke of Transylvania Thomas Szécsényi, after the death of William, took not only those counties and fortresses that William held in the northeast of the country as a royal baron, but also all the estates he was once personally given by Charles Robert. ${ }^{30}$ Despite the fact that William's last will named as the successor to all his fortresses and estates his younger brother Nicolas, ${ }^{31}$ this was not a sufficient legal argument for the Drugeths to keep their estates. On 7 January 1343 , at the royal palace in Visegrad, William's two younger brothers Nicholas and Jean

\footnotetext{
${ }^{26}$ Kurcz 1988: 106-110, 139-140.

${ }^{27}$ On the Drugeths as the bearers of aristocratic culture in the society of new Anjou aristocracy: Hardi 2014: 212-223.

${ }^{28}$ More details on the date of the death of William Drugeth: Piti 2006: 435-441; compare Anjou, XXVI, no. 479, 331; no. 489, 336-337; no. 493, 338

${ }^{29}$ Maria Follia's document was preserved as a copy in the confirmational charter of King Lajos. F, IX/1, 104; Anjou, XXVII, no. 47, 77; compare Hardi 2017: 167-173.

${ }^{30}$ On political and legal circumstances of the fall of the family of Drugeth: Engel 1997: 146; Id. 1997: 145-148; Also Piti 2006: 435-441; Hardi 2012: 340-152; Zsoldos 2017: 187-202.

${ }^{31} \mathrm{D} 171270$.
} 
appeared before the highest court of the Hungarian kingdom - young King Lajos, his mother Queen Elizabeth, the prelates and barons of the kingdom - in an attempt to use valid documents to protect their hereditary rights after their brother's death. After reviewing the charter, this court decided that Nicholas and Jean had no right (nullum ius habere) to the estates of William Drugeth that he personally acquired or inherited from his predecessors, palatine Phillip and father Jean, and that, therefore, it belonged to the "royal hands." On that occasion it was also pointed out that William was "absque haeredem solatio ab huius mundi ergastulo sublato." Still, taking into account the faithful service and merits of the three palatines, as well as both Nicholas and Jean themselves, and not wanting them to be left with nothing, Lajos decided to give the fort of Nevicka that was now his, the free settlement of Zemplin with customs and estates in the Zemplin County, as well as another two fortresses, Brekov and Jasenov in the same county to the magistrates Nicholas and Jean Drugeth and their heirs. ${ }^{32}$ It was a small and incomparably poorer part of the former wealth of the Drugeth palatine family. At the same time, Nicholas Drugeth soon lost his official position on the royal court among royal barons because 7 January 1343 was the last time he had the baron's title of the royal cup bearer (magister pincernarum eiusdem domini regis), which he had had since 1332. After this ruling, the Drugeths were formally relegated from the court and in the periphery of the country their power was reduced only to the border county of Ung located below the wooded and uninhabited Carpathian mountains. In truth, for a short time Nicholas Drugeth would return to power and the court as the iudex curie regis (1354-1355) for his merit in the second Italian campaign of King Lajos (during which he was appointed the commander of Salerno), but this would not change the main the political current of marginalization of a once powerful family. ${ }^{33}$ The character of these events, which we can estimate as an unscrupulous political conflict, is also indicated by an event from the biography of Nicholas Drugeth. Namely, it is well known that Nicholas was at one time a teacher (pedagogus) of the young princes Lajos and András and protected their lives during the assassination of Felician Záh on the royal family (1330). ${ }^{34}$

The mere fact that Maria Follia, the widow of William Drugeth, followed Queen Elizabeth during her visit to the Kingdom of Naples and Rome challenges the generally accepted opinion in historiography regarding the collapse of power and the suppression from the Royal Court of the Drugeths after 1342. This should be somewhat corrected Maria Follia was an exception in relation to her husband's family. This was only one woman and a widow at that, but it is quite possible that this status, in addition to some other essential reasons, enabled Maria Follia to protect her interests. In fact, we can prove that Queen Elizabeth cared very much that William's widow would accompany her during the upcoming, politically complicated and uncertain journey to Italy. This opinion is unequivocally confirmed by an announcement that came from the contents of a donation charter that King Lajos issued on 3 June 1343.

We have learnt from the charter that the king, "with the permission, advice and at the will of his mother," because of the respect for the faithfulness and merit of the late palatine,

\footnotetext{
${ }^{32}$ Molnár 1911: 134-137; compare Anjou, XXVII, no. 14, 51.

${ }^{33}$ Engel 1996: 7, 43, 219; Hardi 2012: 380-404.

${ }^{34}$ Szentpétery, SRH, I, 494; recent sources on the assassination of Felician Záh: Almási 2004: 191-197.
} 
his orphans and widow Maria (“...Villermi Palatini orphanis... Nobili Dominae, Mariae, relictae eiusdem Villermi Palatini...”), gave her an estate in Visegrad. This was an estate where wooden and stone structures were erected. ${ }^{35}$ The charter is very important for several reasons for the history of the Drugeth family and the fate of Maria Follia. This is where we learn that Maria and William did have children, who were underage in 1343 and obviously female, which was indirectly indicated by the content of the previously shown royal charter of 7 January 1343. On the other hand, we also know that the Drugeth family had two curia (the palace with the office) in the capital of Visegrad. ${ }^{36}$ One directly went to Maria as a widow and the other, at least formally, in the meantime came into possession of the royal crown along with other possessions of her husband. However, as we see, at the initiative of the Queen Mother this other estate in the capital was subsequently given to Maria and her children. The key detail regarding this royal donation is the date of its publication -3 June 1343 - therefore, the privilege occurred only five days before Queen Elizabeth went to Italy. It was as if the goal of this donation was to reward the widow of the palatine Maria Follia for the upcoming journey. We believe that this was the proof of the prominent place intended for Maria in the queen's company over the coming months. Finally, the friendly relationship between the Queen with the widow of William Drugeth, along with all the arguments already presented, can be proven by another gift given in Naples, which is also another source that confirms the stay of Maria Follia in Naples and Rome during 1343-1344.

After Queen Elizabeth returned from Rome to Naples, Maria Follia used the position of the Queen's companion to exercise her alleged widow right to William's family estate in Naples. So we learn that on 3 January 1344 in her quarters Queen Joanna, at the request of her loyal subject (fidelem nostram) Maria Follia, the widow of "Guillermi Drugetti Magni comitis Regni Ungarie," on the basis of "iribus suarum dotum" gave to the same noblewoman the estate "Casalis Pascarole partium Civitatis Averse" with the obligation of giving feudal service. This donation was made by Queen Joanna, as stated in the charter, out of respect for "her mother," the Hungarian Queen. ${ }^{37}$ This was an additional confirmation of Queen Elizabeth's affection for Maria Follia as she appears to have advocated at the Naples court that her lady acquire the right to the Pascarole estate. The medieval settlement of Pascarole in the area of the town of Averse belonged to the Drugeth family continuously since 1271 as their main family property in the Kingdom of Sicily. The last in the series of lords of the estate (feudatarius) was Maria's husband William. ${ }^{38}$ We are not at all sure that Maria had a widow's right this entire estate in comparison to her late husband's brothers Nicholas and Jean Drugeth, who we can rightly conclude did not receive an invitation to accompany the queen on her journey to Naples. ${ }^{39}$ And finally, the question arises whether Maria consulted with them about her intentions or if she acted independently. There is a hypothetical possibility that in this way she actually wanted to save the Naples family estate, which, after the death of William without a male heir and in the absence of Nicholas and

\footnotetext{
${ }^{35}$ F, IX/1, 105-106; Anjou, XXVII, no. 374, 274.

${ }^{36}$ F, IX/1, 102-105; Anjou, XXVII, no. 47, 77; Hardi 2012: 359-360.

${ }^{37}$ Wenzel, Acta extera, II, 40-41.

${ }^{38}$ Hardi 2012: 40-369.

${ }^{39}$ On the widow's rights in medieval Hungary and Europe with a detailed literature review: Hudáček 2013: 227 262; isto u: Id. 2014: 3-39.
} 
Jean, also should have gone to the ruler of Naples. In any case, Maria was well acquainted with the property of her husband's family in the kingdom of Naples and did not lack entrepreneurial spirit.

In the absence of sources it will remain unknown if during 1343-1344 Maria took the opportunity to visit Pascarole, which was located near Naples, and force the local vassals and subjects to fulfill their obligations to the Drugeth family. Unlike this unsolvable question, it seems quite possible that Maria Follia followed her mistress during her magnificent visit to Rome, when Elizabeth was greeted with cheers by all the Roman people led by the representatives of the main families of Colona and Orsini located on opposite sides of the river Tiber. ${ }^{40}$ According to an anonymous Roman chronicler, the Hungarian queen arrived in the city in a carriage with four horses. In the carriage opposite her there sat eight noblewomen (comitisse), who did not divert their eyes from their mistress. They were followed by a second carriage with noble Hungarian mistresses (mulieres Nobiles, Hungaricis) who, as this eyewitness noticed, had golden strips in their hair and scarves. The queen's carriage was surrounded by 50 knights with golden spurs, accompanied by numerous servants. ${ }^{41}$ There is no doubt that in the mentioned two carriages sat the most distinguished court ladies, wives or daughters of the most important Hungarian barons, who were at the same time the queen's friends and companions. At least according to the abovementioned findings, it is possible to assume that one of them was Maria Follia. Of course, this is only our hypothesis, which is closely followed by another source.

Historians are well aware of the fact that during her stay in Rome, Elizabeth generously gave to the poor and endowed the church and priests with expensive gifts and through this prism should we understand the enthusiastic welcome of the Romans. ${ }^{42}$ In the inventarium of the Church of St. Peter compiled in 1361 a detailed description of the gifts that the Hungarian pilgrims brought to the Church of St. Peter was preserved. Elizabeth gave numerous gifts of sophisticated craftsmanship and great value. The catalogue of donated items "per reginam Ungarie" lists, among other things, a lavish wall carpet designed for the space behind the altar with nine paintings of saints, among which were the Hungarian saints; a purple silk tablecloth with the image of Mary with the dead Jesus; then a whole series of liturgical garments made of the most expensive materials - blue silk, Indian silk, silk with golden embroidery etc.; church cups and other dishes, among which was prominent a pure golden cup with precious stones and pearls, as well as a silver cup filled with 600 gold florins. ${ }^{43}$ The editors of this source, Eugenio Müntz and Arthur Frothingham, already noted that the actions of their mistress were followed by the most distinguished courtiers, according to the principle imitatio Reginae. ${ }^{44}$ It was listed that a purple riza sewn on a fabric called "diasperus" with gorgeous zoological and floral motifs decorated with pearls was

\footnotetext{
${ }^{40}$ Ch.H: 163 .

41 „Regina haec Hungarie in rheda deducebatur. Rhedam quator equi vehebant. Octo Comitisse cum ipsa consedebant, vultuque ad Reginam converso, eam singulae intuebatur. In altero curru deductae prosequebantur aliae mulieres Nobiles, Hungaricis velis \& corollis purioris auri in capite orantae. Quinquaginta Milites ad aurea culcaria circumstipabant Reginae rhedam. Famulitium aliud subsequebatur.“ Hist. Rom. Fragmenta: 318.

${ }^{42}$ Karácsonyi 1893: 50-62; Pór 1893: 680-683; Dąbrowski 1914: 55-56; Csukovits 2003: 70-71.

${ }^{43}$ Müntz, Frothingham 1883: 14, 17, 32, 47, 48, 133; Karácsonyi 1893: 58-62.

${ }^{44}$ Müntz, Frothingham 1883: 51, footnote no. 2.
} 
"donata per unam comitissam de Ungaria." 45 The second gift, a fabric made of tatar silk with golden threads showing men, women, animals, flowers and plants was a gift "donat.[us] per quamdam comitissam sotiam regine Ungarie." ${ }^{6}$ That comitissa Maria Follia was the sotia of Queen Elizabeth on her journey to Italy is undisputed, but the possibility to identify her as a bestower of these gifts will remain a matter of a historiographical hypothesis.

On the basis of what has been said so far it remains in the final part of the paper to answer the question of why Maria Follia had a predetermined place in Queen Elizabeth's company on her journey to Italy and why the widow of the palatine had avoided the fate of a political conflict with her husband's family. Two answers or presuppositions spring to mind. The first one is that Queen Elizabeth and Maria were friends while their spouses were alive and that they remained relatively close after their almost simultaneous death. It is also possible that the queen, herself becoming a widow, had understanding with respect to the protection of Maria's rights as a widow. Of course, we are not even considering idealizing their relationship and we must keep in mind that "the closeness with the queen" at the time of the loss of the power of the Drugeth family was, above all, in the interest of Maria himself in order to keep her position in the court and at least part of the wealth of her late husband. The second answer concerns the expectations and interests of Queen Elizabeth himself. We have neglected to say that we know the origins of the wife of the palatine William Drugeth. ${ }^{47}$ She, like her husband's family, originated from the kingdom of Naples and undoubtedly belonged to the circle of nobility (Ultramontani) who came to Italy with Carl I Anjou. Antal Pór, an expert on the history of Hungary in the Anjou era, made a laconic assumption that Maria was French. ${ }^{48}$ Maria's last name, which in the older literature was mistaken for a personal name, depending on the source was recorded in the orthographic forms of "Folya,"49 "Follia," 50 "Feulie." 51 Among the knights of Charles I, King of Sicily, in 1283 there was mention of a certain "Ernulfus de la Folia." 52 Four decades later, in 1324, the line of Anjou barons and feudatories from the Province of Principatus who were called into the war against the Aragonese included "dominus Everaldus Follia" and his son "Guillelmus de S. Severino," as well as another feudal master "miles Geraldus de Follia." 53 At least two branches of the Follia family, therefore, lived at that time in southern Italy in the city of San Severino. In all likelihood, Maria's parents or brothers should be sought among the aforementioned noblemen and this implies that in her social status and origin she was equal to her husband, William Drugeth. Unfortunately, we do not know when and where Maria became William's wife (datum ante quem 9. Avgust 1330), whether it was at the time when this branch of the Drugeth family lived at the court of the French queen Clementia, where

\footnotetext{
${ }^{45}$ Müntz, Frothingham 1883: 41; for the interpretation of the text in Latin compare: Karácsonyi 1893: 61.

${ }^{46}$ Müntz, Frothingham 1883: 44; Karácsonyi 1893: 62.

${ }^{47}$ More details in Hardi 2012: 253-355.

${ }^{48}$ Pór 1893: 428.

${ }^{49}$ Dl. 71270; F, IX/1, 102-103.

${ }^{50}$ Wenzel, Acta extera, II, 40.

${ }^{51}$ Bossányi, Regesta supplicationum: no. 265, 137.

${ }^{52}$ Durrieu 1887: 254, 320.

${ }^{53}$ Camera 1860: 299-300.
} 
the future palatine of Hungary, William, was the queen's squire (Escuyers).$^{54}$ It seems probable that she arrived to Hungary along with William (about 1327).

To conclude, Maria was a foreigner in Hungary. However, she was not a foreigner in the Kingdom of Naples. According to available sources, she was perhaps not even among the rare but the only court lady of the Hungarian queen Elizabeth who understood without a mistake and spoke the language of the ruling elite in southern Italy. As the daughter-inlaw of the Drugeths, a family that had been in the court service of members of the Anjou Dynasty for several generations, we can accept the assumption that Maria was also familiar with the court protocols and the culture of behaviour at the Naples Royal Palace. It is quite possible that she had direct ties to the local aristocracy and her relatives, from whom she could receive very important information. In comparison to the royal Visegrad on the Danube, the Royal Naples was a medieval megapolis and a political centre of Europe of that time. Queen Elizabeth Łokietek, born somewhere in the Slavic north of Europe, actually headed towards the unknown when she started her journey on 8 June 1343 and therefore it was very important to have with her, as her closest companion - sotia and counselor - her old acquaintance, distinguished Maria Follia.

Maria Follia most likely, as was expected, returned from the kingdom of Naples together with the queen to Hungary in May $1344 .{ }^{55}$ We can conclude that her stay in Italy was successful, first of all because of the donations that accompanied it and they referred to the estates of her late husband that formally became Maria's property now. Although in the years to come we would not meet Maria in the immediate company of the queen, other sources indirectly indicate that she remained at the mercy of the ruling family. The last active mention of this aristocrat was on 5 June $1358 .{ }^{56}$ On the other hand, Queen Elizabeth, besides her moments of glory, in the intricate diplomatic web of the Naples court and the papacy did not achieve much in terms of establishing the position of her younger son András in Naples. As it is well known, on 18 September 1345 in Aversa he would die as a victim of a cruel court conspiracy. ${ }^{57}$

\section{SOURCES:}

Anjou = Anjou-kori oklevéltár, Dokumenta res Hungaricas tempore regum Andegavensium illustrantia 1301 - 1387, I-XL, Kristó Gy.... Piti F. et al. (eds.) Budapest-Szeged: JATE; Szegedi Tudományegyetem et al., 1990 - 2014.

Bossányi, Regesta supplicationum $=$ Regesta supplicationum, A pápai kérvénykönyvek magyar vonatkozású okmányai, Avignoni korszak, I, Bossányi A. (ed.), Budapest: Stephaneum Nyomda R.T., 1916.

Ch.H = Thurocz, Johannes de. Chronica Hungarorum, I, Textus, eds. E. Galántai and Gy. Kristó. Budapest: Akadémiai Kiadó, 1985.

\footnotetext{
${ }^{54}$ Hardi 2012: 242.

${ }^{55} \mathrm{Z}$, II, 106.

${ }^{56}$ Dl, 87333; more details: Hardi 2012: 370-379.

${ }^{57}$ Miskolczy 1928: 766-800; Hóman 1938: 318-322; Léonard 1954: 315-319, 343-344.
} 
Dl = Magyar Országos Levéltár, Budapest, Mohács etőtti gyüjtemény (Collectio Antemohacsiana).

$\mathrm{F}=$ Codex diplomaticus Hungariae ecclesiasticus ac civilis, I-XI, Budae: Typis typogr. Regiae Universitatis Ungaricae, 1829 - 1844.

Hist. Rom. Fragmenta = 'Historiae Romanae Fragmenta', in: L. A. Muratori (ed.), Antiquitates Italicae Medii Aevi, III, Mediolani 1740, 251-548.

Molnár, G. 'Levelek a Homonnai Drugethek család - és jószágtörténetéhez (1342-1551) ', Adalékok Zemplénvármegye Történetéhez, 5-8 szám, 1911, 129-137.

Müntz, E., Frothingham A. L. 'Il Tesoro della basilica di S. Pietro in Vaticano dal XIII al XV secolo con una scelta d'Inventarii inediti', Archivo della Società Romana di Storia patrina, VI, 1883, 1-137.

$\mathrm{SRH}=$ 'Joannes de Thwrocz, Chronica Hungarorum ab orgine gentis, inserta simul chronica Joannis Archidiaconi de Kukullew', in: Scriptores rerum Hungaricarum, I, Cura et studio Ioannis Georgii Schwandtneri, Tyrnaviae: Typis Collegii Academici Societatis Jesu, 1765.

Szentpétery, SRH, I = 'Chronici Hungarici compositio saeculi XIV', Textum recensuit Alexander Domanovsky, in: Scriptores rerum Hungaricarum tempore ducum regumque stirpis Arpadianae gestarum, Szentpétery E. (ed.), I, Budapestini: Budapestini Typ. Reg. Univ. Litter. Hung. 1937, (reprint: Nap Kiadó 1999).

Wenzel, Acta extera = Magyar diplomacziai emlékek, Monumenta Hungariae Historica, Acta Extera, Wenzel, G. (ed.), I- II, Budapest: MTA, 1874-1875.

Zichy = A zichi és vásonkeői gróf Zichy-család idösb ágának okmánytára. Codex diplomaticus domus senioris comitum Zichy de Zich et Vasonkeo, I-XII, Nagy, Imre - Nagy, Iván - Véghely, Dezsö (eds.), Pesten; Budapest: Kiadja a Magyar Tört. Társulat, 1871-1931

\section{REFERENCES:}

Almási, T. 'Záh Felicián ítéletlevele', Aetas, 1-2, 2000, 191-197.

Caggese, R. Roberto d'Angiò e i suoi tempi, I-II, Firenze: R. Bemporad, 1922-1930.

Camera, M. Annali delle Due Sicilie: dall' origine e fondazione della monarchia, II, Napoli: Stamperia e cartiere del Fibreno, 1860.

Csánki, D. Magyarország történelmi földrajza a Hunyadiak korában, I, Budapest: MTA, 1890.

Csukovits, E. Középkori magyar zarándokok, Budapest: MTA Történettudományi Intézet, 2003.

Durrieu, P. Les archives angevines de Naples, étude sur les registres du roi Charles I-er (1265-1285), II, Paris: Ernest Thorin Éditur, 1887.

Engel, P. ‘Honor, vár, ispánság', Századok, 116, 1982, 880-922.

. Magyarország világi archontológiája, I, Budapest: História, MTA Történettudományi Intézete, 1996.

. 'Nagy Lajos ismeretlen adományreformja', Történelmi Szemle, 2, 1997, 137-157.

Hardi, Đ. Drugeti, povest o usponu i padu porodice pratilaca anžujskih kraljeva, Novi Sad: Filozofski fakultet u Novom Sadu, 2012.

. 'Meinardus Medicus Domini Palatini', in: Gogola, M, Ribár, L. (eds.), Ján Jessenius (1566 1621) - Ludia a doba, Bratislava: STIMUL, 2017, 167-173.

. 'Obrazy z každodenného života šlachtickej rodiny Drugethovcov ako paradigma rytierskej kultúry a spôsobu života novej aristokracie', Historický časopis, 62 (2), 2014, 203-224.

Hóman, B. Gli Angioini di Napoli in Ungeria 1290-1403, Roma: Reale accademia d'Italia 1938. . A magyar királyság pénzügyei és gazdáságpolitikája Károly Róbert korában, Budapest: Kiadja a Budavári Tudományos Társaság, 1921 (reprint: Nap Kiadó, 2003).

Hudáček, P. 'Právne postavenie vdovy v stredovekom Uhorsku do roku 1222 a otázka venného', Historický časopis, 61 (2), 2013, 227-262. 
Hudáček, P. 'The Legal Position of Widows in Medieval Hungary up to 1222 and the Question of Dower', Historický časopis, Supplement 62, 2014, 3-39.

Karácsonyi, J. ' Nagy Lajos anyja Rómában', Katholikus szemle, 50 kötet, 1893, 50-63.

Köblös, J. 'Kükülley János', in: Kristó Gy. (ed.), Korai magyar történeti lexikon (9-14. század), Budapest: MTA, 1994. 576-577.

Kristó, Gy. Makk, F. Károly Róbert emlékezete (A szöveganyagot válogatta, szerkesztette, a bevezetöt és a jegyzeteket írta Kristó Gyula és Makk Ferenc, A képanyagot Marosi Ernő válogatta), Budapest: Európa Könyvkiadó, 1988.

Kurcz, Á. Lovagi kultúra Magyarországon a 13-14. században, Budapest: Akadémiai Kiadó, 1988.

Léonard, É, Les Angevins de Naples, Paris: Presses universitaires de France, 1954.

Malovecká, Mi. Karol Wagner 1732-1790 historik Spiša a Šariša, Prešov: Vydavatel'stvo Michala Vaška, 2009.

Mályusz, E Thurocz, Johannes de. Chronica Hungarorum II, Commentarii 2, Ab anno 1301 usque ad annum 1487, Composuit Elemér Mályusz, adiuvante Julio Kristó, Budapest: Akadémiai Kiadó, 1988.

Miskolczy I. 'András herceg tragédiája és a nápolyi udvar', Századok, 1928, 766-800. . ‘Magyar-olasz összeköttetések az Anjouk korában', Budapest: Szent István-Társulat, 1937.

Piti, F. 'Az 1342. évi nádorváltás', Századok, 140 (2), 2006, 435-441.

Pór, A. Nagy Lajos 1326-1328, Budapest: Magyar TörténelmiTársulat, 1892. . 'A történeti jelenetek korhű reconstruálásáról', Századok, 1893, 420-428, 504-511, 680-693.

Szende, L. 'Łokietek Erzsébet a 14. századi hazai elbeszélő forrásokban' in: Almási, T., Draskóczy, I., Jancsó, É. Studia professoris - professor studiorum: tanulmányok Érszegi Géza hatvanadik születésnapjára, Budapest: Magyar Országos Levéltár, 2005, 333-341.

Uličný, F. Dejiny osídlenia Zemlínskej župy, Mihalovce: Občianske združenie Zemplínska spoločnost', 2001.

Wagner, C. Collectanea genealogico-historica ilustrium Hungariae que jam interciderunt, Decas III, Posonii, Pestini et Lipsiae: typis et sumptibus Joan, Michaelis Landerer, 1802.

Wertner, M. 'Magyar hadjáratok a XIV. században', Századok, 1905, 420-451.

Zsoldos A. A Druget-tartomány története 1315-1342, Budapest: MTA Bölcsészettudományi Kutatóközpont Történettudományi Intézet, 2017. 


\author{
ЂУРА ХАРДИ \\ Универзитет у Новом Саду \\ Филозофски факултет, Одсек за историју
}

\title{
МАРИА ФОЛИА \\ ДВОРСКА ДАМА УГАРСКЕ КРАЉИЦЕ ЕЛИЗАБЕТЕ ЛОКИЈЕТЕК - У ПРАТЫИ ГОСПОДАРИЦЕ НА ПУТОВАњУ У ИТАЛИЈУ
}

\begin{abstract}
Резиме
Путовање и боравак угарске краљице Елизабете Локијетек, мајке краља Лајоша Великог и удовице краља Карла Роберта, у Напуљској краљевини и Риму од јуна 1343. до маја 1344. године, добро је истражена тема у историографији. Краљицу је на том путу, како бележи угарски хроничар, пратио њен двор, бројне дворске даме, девојке племенитог рода, угарски барони, витезови и слуге. Ипак, од целокупног женског дела краљичине пратње остао је познат само идентитет једне њене дворске даме, аристократкиње Марије Фолије. Марија је била удовица недавно преминулог угарског палатина Виљема Другета (умро у септембру 1342. године). О њеном присуству у (најближем) окружењу краљице сведоче два дипломатичка извора, један угарске, а други напуљске провенијенције. Први представља судску исправу јудекса курије Пала издату 17. марта 1344. године у којој се одлаже судски спор на 15. дан од повратка краљице Елизабете из Италије у Вишеград, јер је једна страна у спору тврдила да није у могућности да прикаже извесне повеље које се налазе у рукама удовице палатина Виљема, која се налазила заједно са краљицом на путу у „прекоморским земљама”. Други документ је повеља коју је 3 . јануара 1344. године издала напуљска краљица Ђована у Напуљу на молбу Марије Фолије. У њој се удовици палатина, на име њених удовичких права, поклања породични посед Другета, „Casalis Pascarole partium Civitatis Averse“. Аутор рада истражује узроке и сложене околности под којима је Марија узела учешће на италијанском путовању своје господарице. Питање је тим занимљивије јер је познато да након смрти палатина Виљема (који у браку са Маријом није имао мушког наследника), породица Другет - као најмоћнија угарска баронска породица, губи власт, богатства и позиције на краљевском двору. Марија Фолија је након 1342. године избегла судбину породице свог супруга. Остала је у добрим односима с краљицом Елизабетом и сачувала је своје позиције на краљевском двору. Краљица Елизабета и краљ Лајош су чак настојали да придобију Марију за њено учешће у италијанској експедицији, о чему речито говори краљевска даровница издата Марији и њеним малолетним ћеркама, непосредно пре поласка на пут (3. јуна), за посед једне курије у престоном Вишеграду који је за живота припадао покојном Виљему, а у међувремену био враћен у краљевске руке. Намећу се две претпоставке с којима се може појаснити околност да је Марија Фолија сачувала своје друштвене позиције и део породичног богатства. Прва је да су краљица Елизабета и Марија биле пријатељице током живота својих супруга и да су остале релативно блиске и након њихове скоро истовремене смрти. Друга претпоставка има децидирани политички контекст. Марија је била Францускиња племенитог рода пореклом из Напуљске краљевине. Њено присуство током неизвесне посете Напуљу и Италији за краљицу Елизабету је било од изузетне важности, јер јој је Марија, као њена пратиља и дворска дама, у многим протоколарним и политичким стварима могла бити важна саветница.

Кључне речи: Марија Фолија, угарска краљица Елизабета Локијетек, породица Другет, Виљем Другет, удовице у 14 веку, Угарска под влашћу династије Анжујаца, угарско-напуљски односи.

